\title{
Pengaruh Rasio Keuangan dan Good Corporate Governance terhadap Basic Earning Power dengan Variabel Moderasi Pertumbuhan Ekonomi
}

\author{
Ihsan Nasihin 1 \\ Fakultas Ekonomi dan Bisnis \\ Universitas Buana Perjuangan, \\ Indonesia
}

\author{
Siska Komala Dewi ${ }^{2}$ \\ Fakultas Ekonomi dan Bisnis \\ Sekolah Tinggi Ilmu Ekonomi Dr Khez \\ Muttaqien, Indonesia
}

\begin{abstract}
Surel : Ihsan.nasihin@ubpkarawang.ac.id
ABSTRAK

Perusahaan memiliki tujuan utama yaitu untuk mencari keuntungan, tetapi banyak faktor yang mempengaruhi perusahaan untuk menghasilkan laba. Tujuan penelitian ini untuk mengetahui faktor-faktor yang mempengaruhi basic earning power. Metode riset dalam penelitian adalah penelitian kuantitatif, dimana data yang digunakan adalah data sekunder. Populasi yang digunakan dalam riset ini berbentuk industri manufaktur sub Property serta Real Esatate yang telah listing di BEI periode 2017- 2019 dengan jumlah populasi merupakan 74 perusahaan. Dalam populasi digunakan metode pengambilan ilustrasi ialah dengan metode Non-Probability Sampling. Hasil penelitian ini menunjukan bahwa Working Capital Turnover, Long Term Debt to Equity Ratio, serta Good corporate governance (GCG) tidak mempunyai pengaruh terhadap Basic Earning Power pada industri sub sektor property serta real estate yang listing di bursa efek Indonesia, sehingga pertumbuhan ekonomi tidak dapat memoderasi rasio keuangan.
\end{abstract}

Kata Kunci: $\quad$ Rasio Keuangan; Good Corporate Governance; Basic Earning Power; Pertumbuhan Ekonomi.

\section{The Effect of Financial Ratios and Good Corporate Governance on Basic Earning Power with Moderating Variables of Economic Growth}$$
\text { ABSTRACT }
$$

Companies have the main objective, namely to seek profit, but many factors influence the company to generate profits. The purpose of this study was to determine the factors that affect basic earning power. The research method in research is quantitative research, where the data used are secondary data. The population used in this research is in the form of the sub-Property and Real estate manufacturing industries that have been listed on the IDX for the 2017-2019 period with a population of 74 companies. In the population, the method of illustration taking is the Non-Probability Sampling method. The results of this study indicate that the Working Capital Turnover, Long Term Debt to Equity Ratio, and Good corporate governance (GCG) have no effect on Basic Earning Power in the property and real estate sub-sector industries listed on the Indonesian stock exchange, so that economic growth cannot moderate financial ratios.
\end{abstract}

Keywords: $\quad$ Financial Ratios; Good Corporate Governance; Basic Earning Power; Economic Growth.

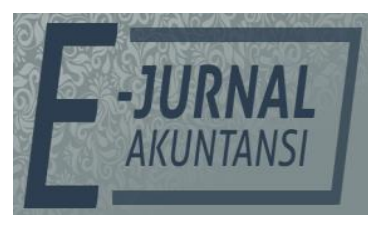

e-ISSN 2302-8556

Vol. 31 No. 8

Denpasar, Agustus 2021

Hal. 2100-2115

DOI:

10.24843/EJA.2021.v31.i08.p17

PENGUTIPAN:

Nasihin, I., \& Dewi, S.K.

(2021). Pengaruh Rasio

Keuangan dan Good Corporate

Governance terhadap Basic

Earning Power dengan

Variabel Moderasi

Pertumbuhan Ekonomi. EJurnal Akuntansi, 31(8), 2100-

2115

RIWAYAT ARTIKEL: Artikel Masuk: 17 April 2021 Artikel Diterima: 16 Agustus 2021

Artikel dapat diakses : https://ojs.unud.ac.id/index.php/Akuntansi/index 


\section{PENDAHULUAN}

Tujuan utama suatu industri yaitu untuk mendapatkan laba yang optimal dengan metode mengutamakan keuntungan untuk owner industri ataupun pemegang saham (Sopyan \& Perkasa, 2019). Laba yang besar yang diperoleh sesuatu industri akan mempengaruhi tingkatan return yang hendak didapat oleh pemegang saham (Suryani \& Fajaryani, 2018). Dengan diperolehnya laba yang optimal serta return yang besar yang diberikan kepada para pemegang saham, sehingga industri akan bisa melaksanakan transformasi ataupun tujuan lain seperti tanggung jawab sosial (corporate social responsibility) serta going concern (Karlina \& Ramadhan, 2020). Tidak hanya laba yang menjadi penanda keberhasilan sesuatu industri, ada faktor lain yang menjadi indikator keberhasilan sebuah perusahaan yaitu kinerja keuangan (Trianto et al., 2017). Kinerja keuangan ialah tujuan ataupun infomarsi keuangan yang membuktikan aktivitas operasional yang telah dicapai oleh sesuatu industri (Suryani \& Fajaryani, 2018). semakin baik kinerja keuangan yang dihasilkan oleh sesuatu industri, makan akan menarik banyak investor untuk menanamkan sahamnya (Dewanti \& Djajadikerta, 2018).

Indikator untuk memandang kinerja keuangan yang dihasilkan sesuatu industri dapat menggunakan metode analisis keadaan profitabilitas perusahan dengan memakai rasio Basic Earning Power (Fatmawati \& Simanungkalit, 2017). Basic Earning Power (BEP) dapat menajdi indikator untuk mengukur keahlian industri dalam menciptakan laba yang optimal (Sopyan \& Perkasa, 2019). Semakin besar nilai Basic Earning Power (BEP) sesuatu industri, maka akan menunjukkan pengelolaan peninggalan industri yang sangat baik dalam menciptakan laba (Karlina \& Ramadhan, 2020). Berikut merupakan grafik Basic Earning Power (BEP) yang dihasilkan industri manufaktur sub zona property serta real estate periode 2017- 2019 yang terdaftar di Bursa Efek Indonesia sebagai berikut.

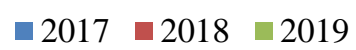

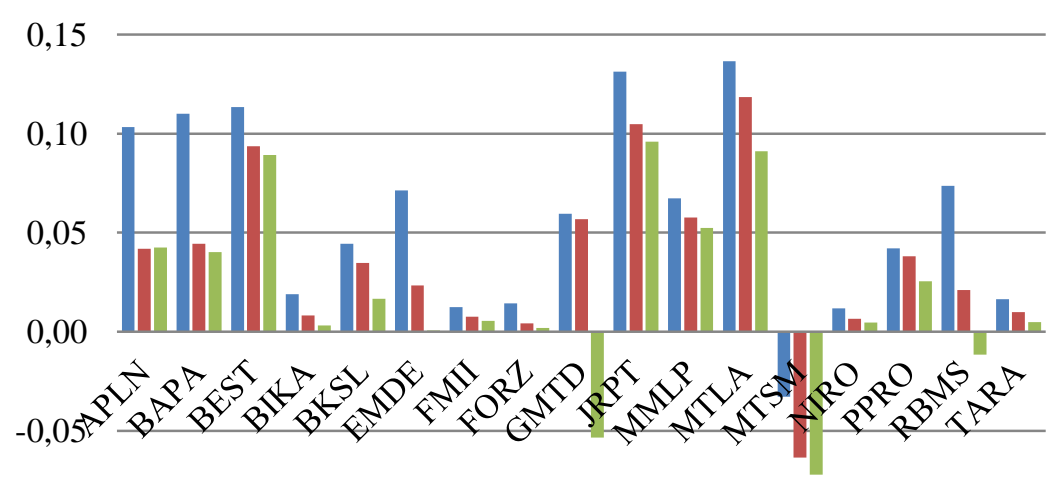

$-0,10$

\section{Gambar 1. Perkembangan Basic Earning Power (BEP) Perusahaan Manufaktur} Sub Sektor Property dan Real estate Periode 2017-2019

Sumber: www.idx.co.id, 2019

Bersumber pada gambar pertumbuhan Basing Earning Power (BEP) perushaaan manufaktur sub sektor property serta real estate tahun 2017- 2019 mengalami penyusutan. Dari 39 industri sub sektor property serta real estate yang terdaftar di Bursa Dampak Indonesia (BEI) pada tahun 2017- 2019, 22 industri 
mengalami peningkatan serta penyusutan yang fluktuatif tiap tahunnya, sebaliknya 17 industri yang lain menghadapi penyusutan tiap tahun.

Tidak hanya kinerja keuangan industri yang dicermati oleh investor untuk menanamkan modalnya, salah satu aspek lain merupakan tata kelola perusahaan (Putri \& Suprasto H, 2016). Tata kelola perusahaan ialah upaya industri untuk membagikan nilai tambah untuk perusahaan dengan metode yang mencermati kepentingan stakeholders ataupun para pemegang saham (Fatchan \& Trisnawati, 2018). Pada saat industri melakukan tata kelola perusahaan yang baik, hingga segala proses aktivitas ataupun kegiatan operasional industri berjalan dengan baik, sehingga dampaknya akan meningkatkan kinerja industri yang bersifat finansial mapun non finansial (Adebayo \& Adebiyi, 2016).

Adapun aspek eksternal yang bisa mempengaruhi industri untuk menciptakan laba adalah Perkembangan Ekonomi (Effendi dan Bahtiar, 2019). Perkembangan ekonomi ialah pertumbuhan aktivitas dalam perekonomian yang menimbulkan benda serta jasa yang hendak dibuat oleh masyarakat mengalami kenaikan (Permata et al., 2018). Salah satu indikator untuk mengukur perkembangan ekonomi adalah Produk Dalam Domestik Bruto (PDB) (Cahyani, 2018). Produk Domestik Bruto ialah nilai mata uang yang dihasikan oleh barang ataupun jasa yang diproduksi oleh suatu negeri (Safitri \& Mukaram, 2018).

Teori Agensi merupakn ikatan kontrak antara agen serta principal (Setiyawati \& Hermawan, 2018). Agen merupakan pihak manajer yang terdapat di industri, sedangkan principal merupakan pihak owner perusahaan (pemegang saham) (Zelmiyanti, 2016). Agen serta principal merupakan dua pihak yang mempunyai tujuan berbeda untuk melaksanakan operasional industri, teramasuk dalam tingkatkan tata kelola industri (Ibadin et al., 2012). Teori keagenan berfungsi sangat berarti dalam pembuatan keputusan ataupun kebijakan perusahaan dalam meningkatkan investasi (Juli \& Umum, 2021).

Laporan keuangan wajib disusun bersumber pada informasi historis yang relevan dengan prosedur akuntansi serta standar akuntansi keuangan, sehingga tujuan untuk membagikan data serta keadaan keuangan perusahaan adalah angka sesungguhnya (Arifuddin et al., 2017). Analisis laporan keuangan pada dasarnya untuk menganalisis kinerja yang dicapai industri pada periode tertentu (Trianto et al., 2017). Hasil dari analisis laporan keuangan bisa digunakan industri untuk membuat strategi industri dalam meningkatkan laba industri (Mardianto \& Tiono, 2019). Analisis laporan keuangan seharusnya dilakukan dengan tata cara serta metode analisis yang sesuai standar agar dapat membagikan hasil analisis yang diharapkan (Erica, 2018).

Salah satu indikator untuk menganalisis laporan keuangan dapat menggunakan rasio keuangan, salah satunya adalah rasio working capital turnover, dalam menganalisis rasio working capital turn over dapat meggunakan metode menyamakan antara penjualan dengan modal kerja ataupun dengan modal kerja rata- rata (Seth et al., 2019). Working capital turnover yang rendah dapat memberikan indikasi penjualan yang dihasilkan tidak cocok dengan modal kerja yang dikeluarkan (Trianto et al., 2017). Sementara apabila working capital turnover yang besar atau meningkat mak akan menampilkan bahwa terbentuknya kelebihan kapasitas (JanrJanrosl, \& Prima, 2018). Tidak hanya working capital turnover yang digunakan untuk menganalisis laporan keuangan terdapat indikator lain yaitu 
Long Term Debt Equity Ratio (LTDER) serta Good corporate governance (GCG) (Adebayo \& Adebiyi, 2016). Long Term Debt Equity Ratio (LTDER) digunakan untuk mengukur serta menganalisis modal sendiri yang disediakan oleh industri untuk jaminan utang jangka Panjang (Veronika et al., 2019). Good corporate governance digunakan oleh setiap perusahaan untuk mengoptimalkan nilai industri dengan metode tingkatkan transparansi, akuntabilitas, tanggung jawab perushaaan, indepedensi, serta kewajaran (Ayu, 2018). Good corporate governance adalah sesuatu sistem yang digunakan untuk mengendalikan serta mengatur industri, dengan tujuan untuk membuat dan meningkatkan nilai tambah (value added) untuk perusahaan (Susilo et al., 2018). Basic Earning Power (BEP) akan menjadi penanda suatu perusahaan dalam mengukur keahlian industri dalam mendapatkan laba yang optimal yang dihasilkan dari aktiva yang dimiliki perushaaan (Sukarmiasih et al., 2015).

Dalam menganilisis laporan keuangan terdapat aspek lain yang menjadi indikator ialah perkembangan ekonomi. Pertumbunan ekonomi adalah aktivitas ekonomi yang dikelola oleh publik meningkat (Rimawan \& Aryani, 2019). Salah satu perlengkapan yang digunakan mengukur perkembangan ekonomi adalah Produk Dalam negeri Bruto( PDB) (Trirahaju, 2017). Produk Dalam negeri Bruto (PDB) adalah proses produksi dalam menghasilkan barang dan jasa oleh sesuatu negara dalam periode tertentu (Leonarski et al., 2019). Produk Domestik Bruto (PDB) bisa digunakan menjadi indikator untuk pengukuran perkembangan ekonomi (Trirahaju, 2017). Nilai PDB bisa juga untuk menjadi cerminan dari kegiatan perekonomian sesuatu negeri (Mooibroek, 2019). Working capital turn over merupakan biasanya digunakan untuk mengukur keefektifan modal kerja selama periode tertentu (Mardianto \& Tiono, 2019). Working capital yang rencah dapat mempengaruhi tingkat laba yang dihasilkan serta modal yang dimiliki, sehingga menghasilkan hipotesis sebagai berikut.

$\mathrm{H}_{1}$ : Working Capital Turnover memiliki pengaruh terhadap Basic Earning Power.

Long term debt to equity rasio biasanya digunakan untuk mengukur seluruh hutang yang dimiliki oleh perusahaan dapat membiayai aktiva yang dimiliki (Rimawan \& Aryani, 2019). Sehingga rasio Long Term Debt to Equity Ratio dapat mempengaruhi laba yang dihasikan oleh perusahaan, untuk itu dalam penelitian ini menghasilkan hipotesis sebagai berikut.

$\mathrm{H}_{2}$ : Long Term Debt to Equity Ratio memiliki pengaruh terhadap Basic Earning Power.

Good corporate governance merupakan sebuah tata kelola perusahaan, yang mengatur hubungan antara pemegang saham dengan para pengelola perusahaan (Adebayo \& Adebiyi, 2016). Pada saat pelaksanaan Good corporate governance berjalan dengan baik, maka proses operasional perusahaan akan berjalan efektif dan efisien (Erica, 2018). Sehingga dampak yang diakibatkan adalah dapat meningkatkan laba perusahaan, untuk itu dalam penelitian ini menghasilkan hipotesis sebagai berikut.

$\mathrm{H}_{3}$ : Good Corporate Governance berpengaruh terhadap Basic Earning Power.

Pertumbuhan ekonomi merupakan perkembangan ekonomi dan perubahan fundamental ekonomi dari suatu negara (Rimawan \& Aryani, 2019). Pertumbuhan ekonomi merupakan salah satu indikator suatu negara untuk meningkatkan atau menarik investor untuk menanamkan modalnya di negara tersebut (Leonarski et 
al., 2019). Salah satu indikator yang sering digunakan untuk mengukur dan menganalisis pertumbuhan ekonomi adalah Produk Domestik Bruto (PDB) (Trirahaju, 2017). Produk Domestik Bruto (PDB) merupakan proses produksi suatu negara dalam menghasilkan barang dan jasa untuk meningkatkan kesehjatraan negara (Leonarski et al., 2019). Produk Domestik Bruto (PDB) dapat digunakan menjadi indikator dalam mengukur perkembangan ekonomi serta dapat dijadikan sebagai cerminan kegiatan perekonomian suatu negara (Mooibroek, 2019). Jika pertumbuhan ekonomi suatu negara meningkatkan akan berpengaruh terhadap laba perusahaan yang ada di negara tersebut, karena daya beli masyarakan dan proses produksi meningkat. Sehingga dalam penelitian ini menghasilkan suatu hipotesis sebagai berikut.

$\mathrm{H}_{4}$ : Pertumbuhan Ekonomi dapat memoderasi pengaruh Working Capital Turnover terhadap Basic Earning Power.

Pertumbuhan ekonomi merupakan perkembangan ekonomi dan perubahan fundamental ekonomi dari suatu negara (Rimawan \& Aryani, 2019). Pertumbuhan ekonomi merupakan salah satu indikator suatu negara untuk meningkatkan atau menarik investor untuk menanamkan modalnya di negara tersebut (Leonarski et al., 2019). Pertumbuhan ekonomi adalah salah satu faktor penting suatu negara dalam meningkatkan minat investor (Anugrah et al., 2020). Pertumbuhan ekonomi dapat menjadi faktor pendorong suatu perusahaan dalam meningkatkan laba (Seth et al., 2019). Sehingga dalam penelitian ini menghasilkan hipotesis sebagai berikut.

$\mathrm{H}_{5}$ : Pertumbuhan Ekonomi dapat memoderasi pengaruh Long Term Debt to Equity Ratio terhadap Basic Earning Power.

Pertumbuhan ekonomi merupakan salah satu indikator suatu negara untuk meningkatkan atau menarik investor untuk menanamkan modalnya di negara tersebut (Leonarski et al., 2019). Pertumbuhan ekonomi suatu negara yang bagus atau bertumbuh dapat menandakan bahwa negara tersebut melakukan Good corporate governance yang baik (Reyes, 2013). Sehingga Good corporate governance yang baik dalam suatu negara dapat berpengaruh terhadap Good corporate governance perusahaan (Susilo et al., 2018). Good corporate governance yang baik dalam perusahaan akan berdampak pada nilai perusahaan sehingga berdampak pula pada laba yang dihasilkan menjadi meningkat (Arniati et al., 2019). Untuk itu dalam penelitian ini menghasilkan hipotesis sebagai berikut.

$\mathrm{H}_{6}$ : Pertumbuhan Ekonomi dapat memoderasi pengaruh Good corporate governance terhadap Basic Earning Power.

Dalam menganilisis laporan keuangan terdapat aspek lain yang menjadi indikator ialah perkembangan ekonomi. Pertumbunan ekonomi adalah aktivitas ekonomi yang dikelola oleh publik meningkat (Rimawan \& Aryani, 2019). Analisis laporan keuangan pada dasarnya untuk menganalisis kinerja yang dicapai industri pada periode tertentu (Trianto et al., 2017). Hasil dari analisis laporan keuangan bisa digunakan industri untuk membuat strategi industri dalam meningkatkan laba industri (Mardianto \& Tiono, 2019). Salah satu indikator dalam menganalisis laporan keuangan adalah rasio keuangan (Safitri \& Mukaram, 2018). Rasio keuangan biasanya digunakan oleh setiap perusahaan untuk mengukur laba yang dihasilkan (Solihin, 2019), sehingga dalam penelitian ini menghasilkan hipotesis sebagai berikut. 
$\mathrm{H}_{7}$ : Rasio keuangan yaitu Working Capital Turnover, Long Term Debt to Equity Ratio serta Good corporate governance memiliki pengaruh terhadap Basic Earning Power.

Pertumbunan ekonomi adalah suatu aktivitas ekonomi yang dikelola oleh publik atau suatu negara dalam meningkatkan pola hidup masyarakat di negara tersebut (Rimawan \& Aryani, 2019). Salah satu indicator yang sering digunakan dalam mengukur perkembangan atau pertumbuhan ekonomi adalah Produk Dalam negeri Bruto( PDB) (Trirahaju, 2017). Produk Dalam negeri Bruto (PDB) adalah proses produksi dalam menghasilkan barang dan jasa oleh sesuatu negara dalam periode tertentu (Leonarski et al., 2019). Pertumbuhan ekonomi suatu negara dapat mendorong tingkat investasi di negara tersebut (Trirahaju, 2017). Sehingga dengan pertumbuhan ekonomi yang meningkatkan, perusahaan yang ada di negara tersebut akan mudah dalam mengelola operasional perusahaannya (Erica, 2018). Pada saat operasional perusahaan berjalan dengan baik tentu akan berdampak pada laba perusahaan (Azis \& Hartono, 2017). Adapun hipotesis yang dihasilkan dalam penelitian ini adalah sebagai berikut.

$\mathrm{H}_{8}$ : Pertumbuhan Ekonomi dapat memoderasi pengaruh Working Capital Turnover, Long Term Debt to Equity Ratio serta Good corporate governance menjadi berpengaruh terhadap Basic Earning Power.

Menurut (Solihin, 2019) current ratio dan total asset turn over memiliki pengaruh terhadap basic earning power, tetapi penelitian Marpaung, (2017) menyatakan bahwa perputaran modal kerja dan total asset turn over tidak berpengaruh signifikan terhadap basic earning power, pendapat lain yaitu (Trirahaju, 2017) menyatakan bahwa total asset turn over berpengaruh positif terhadap basic earning power, menurut (Anugrah et al., 2020) Good corporate governance berpengaruh positif terhadap kinerja keuangan, tetapi peniliti lain yaitu (Azis \& Hartono, 2017) menyatakan bahwa Good corporate governance tidak memiliki pengaruh terhadap kinerka perusahaan, sedangkan (Anugrah et al., 2020) berpendapat bahwa pertumbuuhan ekonomi tidak memiliki pengaruh secara partial dan simultan terhadap profitabilitas, berdasarkan adanya perbedaan pendapat atau gap peniltian yang terjadi, penulis menggambarkan kerangka berpikir atau desain penelitian yang digunakan dalam penelitian ini sebagai berikut.

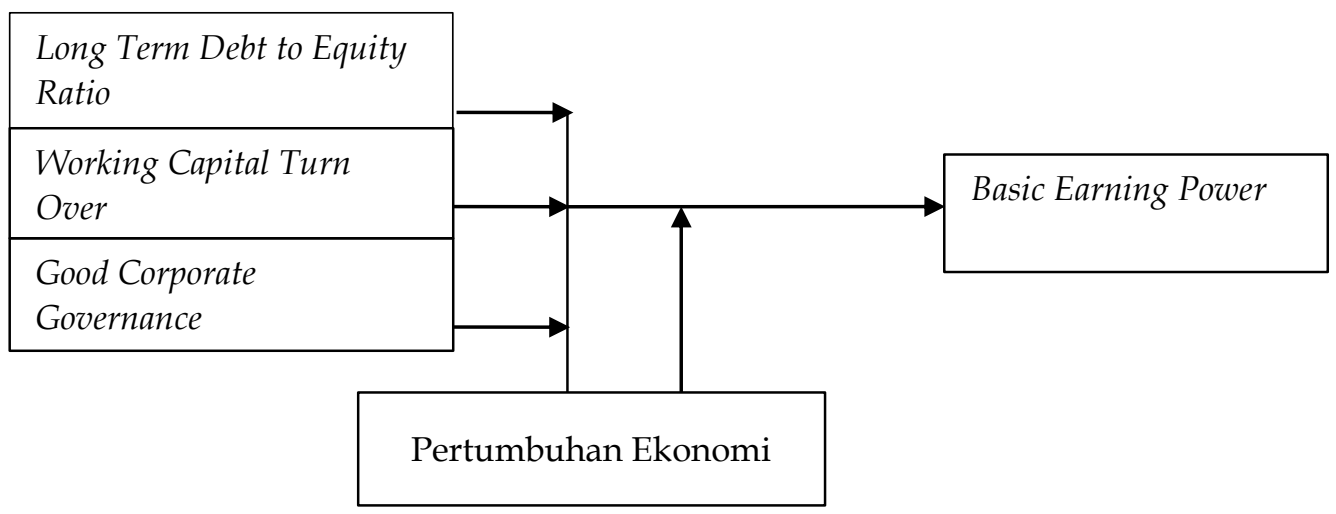

Gambar 2. Desain Penelitian

Sumber: Data Penelitian, 2019 


\section{METODE PENELITIAN}

Metode riset dalam riset ini merupakan riset kuantitatif, dengan metode riset yang digunakan adalah analisis statistik deskriptif, dimana informasi atau data yang digunakan adalah data sekunder. Populasi yang digunakan dalam riset ini berbentuk industri manufaktur sub zona Property serta Real Esatate yang telah listing di BEI periode 2017- 2019 dengan jumlah populasi 74 perusahaan. Dalam populasi digunakan metode pengambilan ilustrasi atau sampel, dengan menggunakan metode Non-Probability Sampling, dengan pendekatan yang digunakan adalah purposive sampling atau pengambilan kriteria berdasarkan pertimbangan dan kriteria dengan krtiteria yang pertama adalah Industri manufaktur sub zona Property serta Real Esatate yang listing di BEI periode 20172019 dan yang kedua adalah industri manufaktur sub zona Property serta Real Esatate yang menyediakan atau memiliki data Good corporate governance pada laporan tahunan secara berkala sepanjang tahun 2017- 2019.

Dalam riset ini menggunakan analisis regresi data panel, dengan menggunakan data cross section dan data time series untuk memudahkan dalam menghasilkan data yang memiliki variabilitas tinggi dan mengurangi kolinieritas antara variabel. Dalam menentukan model regresi data panel yang tepat dilakukan uji chow dan uji haustman. Ditambah untuk lebih mendukung analisis regresi data panel dilakukan juga pengujian asumsi klasik yaitu uji normalitas, uji multikolinieritas, dan uji heteroskedastisitas. Sehingga dapat diambil persamaan regresi data panel yang akan digunakan dalam penelitian ini adalah sebagai berikut.

Yit $=\alpha+\beta_{1} X_{1 i t}+\beta_{2} X_{2 i t}+\beta_{3} X_{3 i t}+\varepsilon_{i t}$

Dalam penilitian ini juga menggunakan uji partial untuk menguji hipotesis yang ada, ditambah dalam mengukur variabel moderasi dalam penelitian ini menggunakan analisis Moderated Regression Analysis. Untuk lebih memperkuat analisis regresi data digunakan juga uji simultan untuk mengukur semua pengaruh variabel yang digunakan dan untuk memudahkan dalam menguji hipotesis yang ada. Sehingga persamaan regresi pada model Moderated Regression Analysis adalah sebagai berikut.

Yit $=a+\beta_{1} X_{1 i t}+\beta_{2} X_{2 i t}+\beta_{3} X_{3 i t}+\beta_{4} M_{i t}+\beta_{5} X_{1} \cdot M_{i t}+\beta_{6} X_{2} \cdot M_{i t}+\beta_{7} X_{3} \cdot M_{i t}+$

$$
\varepsilon_{\text {it }}
$$

\section{HASIL DAN PEMBAHASAN}

Dalam riset ini yang menjadi sampel penelitian adalah salah satu sektor manufaktur yang terdaftar di Bursa Efek Indonesia (BEI) yaitu sub sektor property dan real estate yang memperdagangkan surat berharganya yaitu saham. Teknik pengambilan sampel yang digunakan dalam riset ini adalah nonprobability sampling dengan pendekatan purposive sampling dan diperoleh sebanyak 39 perusahaan sub sektor property dan real estate yang terdaftar di Bursa Efek Indonesia pada tahun 2017-2019. Pemilihan metode analisis data panel dalam riset ini digunakan melalui uji chow dan uji hausman terlebih dahulu, sehingga metode random effect yang paling tepat untuk menguji data panel pada penelitian ini. Berikut ini adalah hasil analisis regresi data panel dalam penelitian ini. 
Tabel 1. Hasil Analisis Regresi Data Panel

\begin{tabular}{lcccc}
\hline \multicolumn{1}{c}{ Variable } & Coefficient & Std. Error & t-Statistic & Prob. \\
\hline C & $-0,018$ & 0,056 & $-0,323$ & 0,746 \\
WCTO & 0,026 & 0,059 & 0,439 & 0,660 \\
LTDER & 0,005 & 0,095 & 0,589 & 0,556 \\
GCG & 0,095 & 0,083 & 1,146 & 0,254 \\
R-squared & \multicolumn{2}{c}{ Weighted Statistics } & \\
Adjusted R-squared & 0,016 & Mean dependent var & 0,020 \\
S.E. of regression & $-0,009$ & S.D. dependent var & 0,030 \\
F-statistic & 0,031 & Sum squared resid & 0,106 \\
Prob(F-statistic) & 0,620 & Durbin-Watson stat & 2,204 \\
\hline Surt & 0,603 & & \\
\hline
\end{tabular}

Sumber: Data Penelitian, 2021

Berdasarkan hasil pengolahan data panel dengan model random effect menghasilkan persamaan regresi sebagai berikut.

$$
\mathrm{BEP}=-0,018+0,026 \mathrm{WCTO}+0,005 \mathrm{LTDER}+\text { 0,095 GCG }
$$

Nilai konstanta yang diperoleh adalah $-0,018$ bernilai negatif, berarti bila variabel independen merupakan nol, hingga besarnya BEP yang dihasilkan merupakan - 0,018. Nilai koefisien regresi WCTO merupakan 0,026 bernilai positif, perihal ini berarti bila WCTO mengalami peningkatan sebesar 1 dalam satuan, maka BEP yang dihasilkan akan mengalami peningkatan sebesar 0,026 dengan anggapan nilai variabel yang lain senantiasa sama. Sehingga jika ada perusahaan yang memiliki nilai BEP positif maka working capital turn over perusahaan tersebut akan meningkat, maka dari itu setiap perusahaan harus dapat meningkatkan penjualannya agar basic earning power yang dimiliki bernilai positif. Nilai koefisien regresi LTDER yang dihasilkan adalah 0,005 dengan bernilai positif, maka dari itu bila variabel LTDER mengalami peningkatan sebesar 1 dalam satuan, maka basic earning power akan mengalami peningkatan sebesar 0,005 dengan anggapan nilai variabel yang lain senantiasa sama. Untuk itu perusahaan yang sudah lisiting di bursa efek harus dapat memperhitungkan total utang jangka Panjang yang dimiliki untuk tetap menjaga efektifitas dan efesiensi pengelolaan seluruh investasi, sehingga nilai basic earning power yang dihasilkan perusahaan tersebut akan bernilai positif.

Nilai koefisien regresi GCG (Good corporate governance) yang dihasilkan adalah 0,095 bernilai positif, perihal ini berarti bila variabel GCG mengalami kenaikan 1 dalam satuan, maka nilai variabel BEP akan mengalami kenaikan sebesar 0,095 dengan anggapan nilai variabel yang lain tetap atau sama. Good corporate governance (tata kelola perusahaan) merupakan ciri atau pengelolaan yang baik atas operasional perusahaan, sehingga jika perusahaan yang sudah di listing di bursa efek menjalankan tata kelola perusahaan yang baik, maka akan meningkatkan minat investor dan meningkatkan nilai investasi, sehingga akan berpengaruh terhadap basic earning power yang dihasilkan perusahaan tersebut. Untuk menguji hipotesis dalam penelitian ini, maka dilakukan uji partial atau uji $\mathrm{t}$, sehingga dalam model ini nilai $t_{\text {tabel }}$ yang diperoleh dengan menggunakan tingkat signifikansi sebesar 0,05 dan nilai degree of freedom $(\mathrm{df})=\mathrm{n}-\mathrm{k}=117-5=$ 112 maka diperoleh $t_{\text {tabel }}=1,981$. 
Tabel 2. Hasil Uji Parsial (Uji t)

\begin{tabular}{ccccc}
\hline Variable & Coefficient & Std. Error & t-Statistic & Prob. \\
\hline C & $-0,018$ & 0,056 & $-0,323$ & 0,746 \\
WCTO & 0,026 & 0,059 & 0,439 & 0,660 \\
LTDER & 0,005 & 0,095 & 0,589 & 0,557 \\
GCG & 0,095 & 0,083 & 1,146 & 0,254 \\
\hline
\end{tabular}

Sumber: Data Penelitian, 2021

Bersumber hasil uji $\mathrm{t}$ yang sudah dilakukan nilai variabel Working Capital Turnover (WCTO) menghasilkan nilai $t_{\text {hitung }}$ sebesar $0,439<t_{\text {tabel }} 1,981$ dengan nilai probabilitas yang dihsailkan sebesar $0,660>0,05$ sehingga akhirnya nilai variabel Working Capital Turnover (WCTO) tidak mempunyai pengaruh terhadap variabel Basic Earning Power (BEP) dan nilai koefisien yang positif akan menunjukkan bahwa kedua variabel mempunyai ikatan yang searah atau sama. Semetara variabel Long Term Debt to Equity Ratio (LTDER) mendapatkan nilai thitung $0,589<t_{\text {tabel }} 1,981$ dengan nilai probabilitas yang dihasilkan adalah $0,557>0,05$ sehingga dapat disimpulkan bahwa nilai atau variabel Long Term Debt to Equity Ratio (LTDER) tidak dapat mempengaruhi terhadap Basic Earning Power (BEP) dan nilai koefisien yang positif menunjukkan bahwa kedua variabel mempunyai ikatan yang searah. Tidak hanya itu variabel Good corporate governance (GCG) memperoleh nilai $t_{\text {hitung }}$ sebesar $1,146<t_{\text {tabel }} 1,981$ dengan nilai probabilitas yang dihasilkan adalah sebesar 0,254>0,05 sehingga kesimpulan yang dapat ditarik adalah variabel Good corporate governance (GCG) tidak dapat mempengaruhi terhadap variabel Basic Earning Power (BEP) dan nilai koefisien yang positif menunjukkan kalau kedua variabel mempunyai ikatan yang searah.

Adapun untuk menguji dan menganalisis variabel moderasi dalam riset ini digunakan uji moderated regression analysis, berikut ini adalah hasil dari uji MRA (Moderated Regression Analysis) sebagai berikut.

Tabel 3. Hasil Uji Moderated Regression Analysis (MRA)

\begin{tabular}{ccccc}
\hline \multicolumn{1}{c}{ Variable } & Coefficient & Std. Error & t-Statistic & Prob. \\
\hline C & $-0,015$ & 0,025 & $-0,618$ & 0,538 \\
WCTO & 0,093 & 0,044 & 2,128 & 0,035 \\
LTDER & 0,026 & 0,030 & 0,852 & 0,396 \\
GCG & $-0,048$ & 0,027 & $-1,777$ & 0,078 \\
WCTO_X_PE & $-0,180$ & 0,085 & $-2,127$ & 0,036 \\
LTDER_X_PE & $-0,510$ & 0,599 & $-0,852$ & 0,396 \\
GCG_X_PE & 0,010 & 0,053 & 1,998 & 0,048 \\
\multicolumn{5}{c}{ Weighted Statistics } \\
R-squared & 0,071 & Mean dependent var & 0,011 \\
Adjusted R-squared & 0,021 & S.D. dependent var & 0,016 \\
S.E. of regression & 0,016 & Sum squared resid & 0,028 \\
F-statistic & 1,415 & Durbin-Watson stat & 2,079 \\
Prob(F-statistic) & 0,215 & &
\end{tabular}

Sumber: Data Penelitian, 2021

Berdasarkan hasil pengolahan data panel yang sudah dilakukan dengan menggunakan model random effect, maka dihasilkan persamaan regresi sebagai berikut.

BEP $=-0,015+0,093$ WCTO + 0,026 LTDER - 0,048 GCG - 0,180 WCTO_PE - 0,510

LTDER_PE + 0,011 GCG_PE + 0,963 
Berdasarkan uji uji moderated regression analysis nilai konstanta yang diperoleh sebesar 0,015 bernilai negatif, berarti bila variabel independen bernilai nol, maka variabel Basic Earning Power (BEP) akan menghasilkan nilai sebesar 0,018. sedangkan nilai koefisien regresi Working Capital Turn Over (WCTO) sebesar 0,093 bernilai positif, perihal ini maka bila variabel Working Capital Turn Over (WCTO) mengalami kenaikan sebesar 1, maka variabel Basic Earning Power (BEP) yang dihasilkan akan mengalami peningkatan sebesar 0,093 dengan anggapan nilai variabel yang lain sama. Untuk itu perusahaan yang sudah listing di bursa efek Indonesia, jika memiliki nilai working capital turn over positif maka akan menghasilkan nilai basic earning power yang positif juga, sehingga perusahaan tersebut dapat menjaga efektivitas dan efesiensi dalam pengelolaan investasinya. Nilai koefisien regresi LTDER sebesar 0,026 bernilai positif, perihal ini berarti bila variabel LTDER menagalami peningkatan sebeasar 1 dalam satuan, maka variabel BEP akan mengalami peningkatan sebesar 0,026 dengan anggapan nilai variabel yang lain sama. Untuk itu dalam meningkatkan nilai investasi perusahaan yang listing di bursa efek maka dibutuhkan pengelolaan utang dan modal yang baik, untuk menghasilkan nilai basic earning power yang positif. Nilai koefisien regresi Good corporate governance (GCG) sebesar 0.048 bernilai negatif, perihal ini berarti bila variabel Good corporate governance (GCG) mengalami peningkatan seebsar 1 dalam satuan, maka variabel BEP akan mengalami penyusutan atau penurunan sebesar 0,048 dengan jumlah nilai variabel yang lain senantiasa sama. Nilai koefisien regresi WCTO_PE sebesar 0,180 bernilai negatif, perihal ini berarti bila variabel WCTO dimoderasi atau dipengaruhi oleh Pertumbuhan Ekonomi (PE), maka akan mengalami peningkatan sebesar 1 dalam satuan, sehingga variabel BEP akan menghadapi penyusutan aau penurunan sebesar 0,180 , dengan anggapan nilai variabel yang lain senantiasa sama. Tidak hanya basic earning power yang menjadi indikator dalam pengelolaan investasi suatu perusahaan, pertumbuhan ekonomi juga dapat mempengaruhi suatu investasi perusahaan sehingga dibutuhkan pertumbuhan ekonomi yang positif untuk meningkatkan nilai perusahaan di kalangan investor. Nilai koefisien regresi LTDER_PE sebesar 0.510 bernilai negatif, perihal ini berarti bila variabel LTDER dimoderasi oleh Pertumbuhan Ekonomi, maka akan mengalami peningkatan sebesar 1 dalam satuan, sehingga variabel BEP yang dihasilkan akan mengalami penyusutan atau penurunan sebesar 0,510 dengan anggapan nilai variabel lain yang didapatkan bernilai sama. Pertumbuhan ekonomi menjadi salah satu faktor suatu investasi, untuk itu diperlukan analisis mengenai PDB (Produk Domestik Bruto) untuk melihat pertumbuhan ekonomi suatu negara, agar investasi perusahaan tersebut dapat meningkat karena tingkat daya beli atau minat masyarakat tersebut sangat tinggi yang akan meningkatkan basic earning power yang dihasilkan suatu perusahaan. Nilai koefisien regresi GCG_PE yang dihasilkan sebesar 0,011 bernilai positif, perihal ini berarti bila variabel Good corporate governance (GCG) dimoderasi oleh Pertumbuhan Ekonomi, maka akan mengalami peningkatan sebesar 1 dalam satuan, sehingga basic earning power yang dihasilkan akan mengalami peningkatan sebesar 0,011 dengan anggapan nilai variabel yang lain senantiasa sama.

Berdasarkan pada tabel uji analisis moderated regression analysis yang menampilkan variabel interaksi WCTO_PE memperoleh nilai $t_{\text {hitung }}$ sebesar $-2,127$ $>t_{\text {tabel }} 1,981$ dengan nilai yang dihasilkan dari probabilitas adalah $0,036>0,05$ 
sehingga akhirnya Pertumbuhan Ekonomi mampu memoderasi pengaruh Working Capital Turnover (WCTO) terhadap Basic Earning Power (BEP). Sedangkan variabel interaksi LTDER_PE menciptakan nilai $t_{\text {hitung }}$ sebesar $0,852<t_{\text {tabel }} 1,981$ dengan nilai yang dihasikan dari probabilitas sebesar 0,396>0,05 sehingga kesimpulan yang bisa ditarik adalah Pertumbuhan Ekonomi tidak sanggup memoderasi pengaruh variabel Long Term Debt to Equity Ratio terhadap Basic Earning Power (BEP), karena nilai koefisien yang dihasilkan adalah negatif, berarti menunjukkan nilai yang dihasilkan dari kedua variabel tersebut ada hubungan yang tidak sesuai. Tidak hanya itu variabel interaksi GCG_PE mendapatkan nominal $t_{\text {hitung }}$ sebesar $1,998>t_{\text {tabel }} 1,981$ dengan nilai probabilitas yang dihasilkan adalah sebesar 0,048>0,05 sehingga kesimpulannya adalah Pertumbuhan Ekonomi mampu memoderasi pengaruh Good Corporate Governanace (GCG) terhadap Basic Earning Power (BEP).

Uji simulan atau uji $\mathrm{f}$ dalam riset ini digunakan untuk menguji apakah variabel independen secara simultan (secara bersama-sama) dapat berpengaruh terhadap variabel dependen. Dalam model ini nilai $F_{\text {tabel }}$ diperoleh dengan menggunakan tingkat signifikansi sebesar 0,05 dan nilai $\mathrm{F}_{\text {tabel }}=(\mathrm{k} ; \mathrm{n}-\mathrm{k})=(5 ; 117-$ $5)=(5 ; 112)$ sehingga nilai $F_{\text {tabel }}$ yang diperoleh sebesar 2,30.

\section{Tabel 4. Hasil Uji Simultan (Uji f) BEP-WCTO-LTDER-GCG}

\begin{tabular}{lrlr}
\hline R-squared & 0,016 & Mean dependent var & 0,020 \\
Adjusted R-squared & $-0,099$ & S.D. dependent var & 0,030 \\
S.E. of regression & 0,031 & Sum squared resid & 0,106 \\
F-statistic & 0,620 & Durbin-Watson stat & 2,204 \\
Prob(F-statistic) & 0,603 & & \\
\hline
\end{tabular}

Sumber: Data Penelitian, 2021

Berdasarkan hasil perhitungan uji simultan menunjukkan bahwa model persamaan dari nilai F-statistic adalah 0,620 $<\mathrm{F}_{\text {tabel }}$ dengan nilai 2,30 dan nilai probabilitas 0,603>0,05, maka dapat disimpulkan bahwa variabel Working Capital Turnover (WCTO), variabel Long Term Debt to Equity Ratio (LTDER) dan variabel Good corporate governance (GCG) secara simultan tidak berpengaruh terhadap Basic Earning Power (BEP).

Tabel 5. Hasil Uji Simultan (Uji f) BEP-WCTO-LTDER-GCG-PE

\begin{tabular}{llll}
\hline R-squared & 0,072 & Mean dependent var & 0,012 \\
Adjusted R-squared & 0,021 & S.D. dependent var & 0,016 \\
S.E. of regression & 0,016 & Sum squared resid & 0,029 \\
F-statistic & 1,415 & Durbin-Watson stat & 2,079 \\
Prob(F-statistic) & 0,215 & & \\
\hline
\end{tabular}

Sumber: Data Penelitian, 2021

Bersumber pada hasil uji simultan yang telah dilakukan akhirnya menghasilkan nilai F-statistic sebesar $1,415<\mathrm{F}_{\text {tabel }} 2,30$ serta nilai dari variabel probabilitas adalah $0,215>0,05$, sehingga akhirnya secara simultan (bersama-sama) variabel Pertumbuhan Ekonomi tidak sanggup memoderasi pengaruh variabel Working Capital Turnover, variabel Long Term Debt to Equity Ratio, serta variabel Good corporate governance (GCG) terhadap Basic Earning Power (BEP).

Industri sub sektor property serta real estate secara rata-rata mempunyai nilai working capital turnover yang fluktuatif yaitu pada tahun 2017 sebesar 1,19 kali, pada tahun 2018 mengalami peningkatan menjadi 3,06 kali, serta pada tahun 2019 kembali mengalami penyusutan menjadi 1,18 kali. Sedangkan rata- rata nilai basic 
earning power mengalami penyusutan setiap tahunnya, dimana pada tahun 2017 industri sub zona property serta real estate mempunyai nilai basic earning power sebesar 0,06 kali, sedangkan pada tahun 2018 sebesar 0,05 kali, dan pada tahun 2019 mngalami penyusutan kembali sebesar 0,04 kali. Hal tersebut membuktikan bahwa jika peningkatan yang dialami oleh working capital turnover tidak dapat diiringi dengan adanya kenaikan tingkat basic earning power. Berarti jika perusahaan memiliki modal kerja yang tinggi belum tentu dapat menghasilkan basic earning power yang positif.

Secara rata- rata nominal yang dihasilkan variabel Long Term Debt to Equity Ratio (LTDER) dari industri manufaktur sub zona property serta real estate sepanjang tahun 2016 hingga tahun 2018 bernilai dibawah 100 persen. Maksudnya industri di sektor ini lebih banyak memakai modal sendiri, jika dibandingkan dengan memakai utang jangka panjang. Namun terdapat pula sebagian industri yang mempunyai nilai Long Term Debt to Equity Ratio (LTDER) diatas 1 ataupun 100 persen semacam industri Alam Sutera Realty Tbk (ASRI), Binakarya Jaya Abadi Tbk (BIKA), Megapolitan Developments Tbk (EMDE), Forza Land Indonesia Tbk (FORZ), Modernland Realty Tbk (MDLN), Plaza Indonesia Realty Tbk (PLIN) serta PP Properti Tbk (PPRO).

Tidak adanya pengaruh dari variabel Long Term Debt to Equity Ratio terhadap variabel independen ialah Basic Earning Power pada industri manufaktur sektor property serta real estate dapat diakibatkan oleh sebagian industri manufaktur sub sektor property serta real estate memiliki rata- rata nilai utang jangka pendek yang sangat besar bila dibandingkan dengan utang jangka panjang yang dimiliki. Sedangkan bila dilihat dari jumlah industri yang jadi ilustrasi atau sampel dalam riset ini sebanyak 39 industri dari tahun 2017- 2019 hanya terdapat 13 industri yang memiliki nilai utang jangka panjang yang lebih besar, sebaliknya sisanya merupakan 26 industri yang memiliki utang jangka pendek yang dimiliki lebih besar. Perbandingan yang mempunyai nilai utang jangka panjang lebih rendah dari pada utang jangka Panjang, hendak mengindikasikan jika industri yang menjadi ilustrasi atau sampel dalam riset ini tidak memakai banyak utang jangka panjang untuk meningkatkan investasi ataupun menambah modal kerja dalam mencari serta meningkatkan laba, sehingga akhirnya riset ini akan membuktikan bahwa variabel Long Term Debt to Equity Ratio tidak mempunyai pengaruh terhadap Basic Earning Power.

Sepanjang tahun 2017- 2019 ada 20 industri manufaktur sub zona property serta real estate dari 39 industri yang menjadi ilustrasi atau sampel dalam riset ini mengalami kenaikan nilai Good corporate governance, namun kenaikan tersebut tidak diiringi dengan meningkatnya keahlian industri dalam mendapatkan laba yang maksimal. Salah satunya industri Megapolitan Developments Tbk (EMDE) yang mempunyai nilai Good corporate governance pada tahun 2017 serta 2018 sebesar 72,49 serta pada tahun 2019 menjadi sebesar 72,75. Tetapi sebaliknya untuk variabel Basic Earning Power (BEP), pada tahun 2017 mempunyai nilai sebesar 0,07, setelah itu tahun 2018 menghadapi penyusutan menjadi sebesar 0,02 serta pada ditahun 2019 menjadi sebesar 0,00. Hal ini jika disimpulkan adalah jika nilai variabel Good corporate governance (GCG) terus mengalami peningkatan maka tidak bisa mempengaruhi peningkatan nilai variabel Basic Earning Power (BEP). 
Pada tahun 2017 pertumbuhan ekonomi Negera Indonesia sebesar 5,07 persen, setelah itu pada tahun 2018 menghadapi peningkatan menjadi sebesar 5,17 persen serta pada tahun 2019 mengalami penyusutan sebesar 5,02 persen. Pertumbuhan ekonomi adalah perkembangan ataupun proses aktivitas dalam perekonomian yang menimbulkan benda serta jasa yang dihasilkan dari proses penciptaan mengalami kenaikan yang signifikan (Mooibroek, 2019). Indikator yang kerap digunakan untuk mengukur peningkatan pertumbuhan ekonomi adalah Produk Dalam negeri Bruto (PDB) (Leonarski et al., 2019). Nilai PDB sesuatu Negera bisa digunakan sebagai acuan dari kegiatan yang dihasilkan oleh perekonomian sesuatu negera pada sesuatu rentang waktu atau periode tertentu (Mooibroek, 2019). Apabila pertumbuhan ekonomi terus mengalami kenaikan, daya beli warga atau masyarakat juga meningkat. Sehingga jumlah produksi yang dihasilkan oleh setiap perusahaan meningkat dan akhirnya berdampak pada keseimbangan daya beli masyarakat yang bertambah (Trirahaju, 2017). Pertumbuhan ekonomi yang bertambah umumnya akan selalu diimbangi oleh peningkatan jumlah pendanaan yang diberikan industri kepada masyarakat agar daya beli masyarakat terus bertambah (Trirahaju, 2017). Pendanaan tersebut dapat bersumber dari eksternal perusahaan (Suryani Ulan Dewi \& Sudiartha, 2018). Pada industri manufaktur sub sektor property serta real estate sepanjang kurun waku tahun 2017- 2019 mempunyai nilai rata- rata utang jangka pendek lebih besar dibanding dengan utang jangka panjangnya, perihal ini maka industri tersebut tidak dapat menggunakan banyak utang jangka panjang untuk meningakatkan investasi ataupun menaikkan modal kerja dalam menjalankan operasional perusahaan untuk meningkatkan keuntungan yang dihasilkan (Dewanti \& Djajadikerta, 2018). Sementara pertumbuhan ekonomi tidak bisa mempengaruhi utang jangka panjang yang hendak digunakan untuk membiayai pendanaan perusaahaan untuk menigkatkan proses operasional perusahaan (Wiksuana, 2018).

\section{SIMPULAN}

Bersumber pada hasil riset yang telah dilakukan pada industri sub sektor property serta real estate yang terdaftar di Bursa Efek Indonesia (BEI) pada tahun 2017- 2019, kesimpulan dalam riset ini adalah Working Capital Turnover, Long Term Debt to Equity Ratio, serta Good corporate governance (GCG) tidak mempunyai pengaruh terhadap Basic Earning Power pada industri sub sektor property serta real estate yang listing di Bursa Efek Indonesia. Sedangkan pertumbuhan ekonomi sanggup memoderasi pengaruh Working Capital Turnover serta Good corporate governance terhadap Basic Earning Power (BEP) pada industri sub sektor property serta real estate yang listing di bursa efek indonesia. Namun pertumbuhan ekonomi tidak sanggup memoderasi pengaruh Long Term Debt to Equity Ratio terhadap Basic Earning Power pada industri sub sektor property serta real estate. Sehingga Working Capital Turnover, Long Term Debt to Equity Ratio serta Good corporate governance secara simultan tidak memiliki pengaruh terhadap Basic Earning Power pada industri sub sektor property serta real estate yang listing di bursa efek indonesia. Serta pertumbuhan ekonomi secara bersama- sama tidak sanggup memoderasi pengaruh Working Capital Turnover, Long Term Debt to Equity Ratio serta Good 
corporate governance terhadap Basic Earning Power pada industri sub sektor property serta real estate.

\section{REFERENSI}

Adebayo, P. A., \& Adebiyi, W. K. (2016). Effect of firm characteristics on the timeliness of corporate financial reporting: evidence from Nigerian deposit money banks. International Journal of Economics, Commerce and Management., IV(3), 369-381.

Anugrah, K., Simanjorang, R. C., Hutabarat, A. R. H., Pakpahan, R. J., \& Sipahutar, T. T. U. (2020). Pengaruh Pertumbuhan Ekonomi dan Inflasi terhadap Profitabilitas pada Perusahaan Makanan dan Minuman di BEI. Owner (Riset Dan Jurnal Akuntansi), 4(2), 442. https:/ / doi.org/10.33395/owner.v4i2.269

Arifuddin, Hanafi, K., \& Usman, A. (2017). Company size, profitability, and auditor opinion influence to audit report lag on registered manufacturing company in Indonesia stock exchange. International Journal of Applied Business and Economic Research, 15(19), 353-367.

Arniati, T., Puspita, D. A., Amin, A., \& Pirzada, K. (2019). the Implementation of Good corporate governance Model and Auditor. 7(1), 188-200.

Azis, A., \& Hartono, U. (2017). Pengaruh Good corporate governance, Struktur Modal, Dan Leverage Terhadap Kinerja Keuangan Perusahaan Pada Sektor Pertambangan Yang Terdaftar Di Bursa Efek Indonesia Tahun 2011-2015. Jurnal Lmu Manajemen, 5(3), 1-13.

Cahyani, Y. T. (2018). Pengaruh Inflasi, Suku Bunga (BI Rate), Produk Domestik Bruto (PDB) Terhadap ROA (Studi Pada Bank Pembiayaan Rakyat Syariah (BPRS) di Indonesia Tahun 2009-2016). IQTISHADIA: Jurnal Ekonomi $\mathcal{E}$ Perbankan Syariah, 5(1), 58. https:// doi.org/10.19105/iqtishadia.v5i1.1695

Dewanti, M. P. R. P., \& Djajadikerta, H. (2018). Pengaruh Kinerja Keuangan dan Tata Kelola Perusahaan Terhadap Nilai Perusahaan pada Industri Telekomunikasi di Bursa Efek Indonesia. Jurnal Akuntansi Maranatha, 10(1), 98-116. https:/ / doi.org/10.28932/jam.v10i1.932

Effendi \& Bahtiar. (2019). Komite Audit, Profitabilitas , Solvabilitas, dan Ketepatan Waktu Pelaporan Keuangan. Bussiness Innovation $\mathcal{E}$ Entrepreneurship Journal, 1(3), 149-157.

Erica, D. (2018). Analisa Rasio Laporan Keuangan Untuk Menilai Kinerja Perusahaan PT Kino Indonesia Tbk. Ecodemica, 2(1), 117-124. https://ejournal.bsi.ac.id/ejurnal/index.php/ecodemica/article/view/291 1

Fatchan, I. N., \& Trisnawati, R. (2018). Pengaruh Good Corporate Governance Pada Hubungan Antara Sustainability Report Dan Nilai Perusahaan (Studi Empiris Perusahaan Go Public di Indonesia Periode 2014-2015). Riset Akuntansi Dan Keuangan Indonesia, 1(1), 25-34. https:/ / doi.org/10.23917/reaksi.v1i1.1954

Fatmawati, A. P., \& Simanungkalit, V. V. (2017). Pengaruh Perputaran Aset Tetap Terhadap Rentabilitas Ekonomi ( Basic Earning Power) Pada PT . Pos Indonesia Persero. 54, 77-86.

García Reyes, L. E. (2013). Pengaruh GCG terhadap Kinerja dan Nilai Persahaan. Journal of Chemical Information and Modeling, 53(9), 1689-1699.

I Gusti AYu, P. W. (2018). Kemampuan Leverage dalam Memoderasi Pengaruh 
Good corporate governance pada Nilai Perusahaan. E-Jurnal Akuntansi, 2018(1), 110-129. https:/ / doi.org/10.24843/EJA.2018.v23.i01.p05

Ibadin, I. M., Izedonmi, F., \& Ibadin, P. O. (2012). Research Journal of Finance \&amp; Accounting. Research Journal of Finance and Accounting, 3(9), 137-144. http://www.iiste.org/Journals/index.php/RJFA/article/view/3159

JanrJanrosl, V. S. E., \& Prima, A. P. (2018). Analisis Faktor-Faktor Yang Mempengaruhi Ketepatan Waktu Pelaporan Keuangan (Studi Pada Perusahaan Perbankan yang Terdaftar di BEI). Fakultas Ekonomi Universitas Diponegoro, 11(1), 61-68. https:/ / core.ac.uk/download/pdf/11721680.pdf

Juli, K. I. A. U., \& Umum, P. (2021). Petunjuk Penulisan Research Paper Konferensi Ilmiah Akuntansi. 3-6.

Karlina, B., \& Ramadhan, M. R. (2020). The Effect of Financial Leverage, Company Sizes, Basic Earning Power and Activity Ratio to Earning Per Share. International Journal of Business Studies, 3(3), 136-141. https://doi.org/10.32924/ijbs.v3i3.135

Leonarski, F., D’Ascenzo, L., \& Auffinger, P. (2019). Nucleobase carbonyl groups are poor Mg 2+ inner-sphere binders but excellent monovalent ion bindersa critical PDB survey. Rna, 25(2), 173-192. https://doi.org/10.1261/rna.068437.118

Mardianto, M., \& Tiono, C. (2019). Analisis Pengaruh Fraud Triangle Dalam Mendeteksi Kecurangan Laporan Keuangan. Jurnal Benefita, 1(1), 87. https:// doi.org/10.22216/jbe.v1i1.3349

Mooibroek, T. J. (2019). Intermolecular non-covalent carbon-bonding interactions with methyl groups: A CSD, PDB and DFT study. Molecules, 24(18). https://doi.org/10.3390/molecules24183370

Permata, A. D., Nurlaela, S., \& Wahyuningsih, E. M. (2018). Pengaruh Size, Age, Profitability, Leverage dan Sales Growth Terhadap Tax Avoidance. Jurnal Akuntansi Dan Pajak, 19(1), 10. https://doi.org/10.29040/jap.v19i1.171

Putri, I., \& Suprasto H, B. (2016). Pengaruh Tanggung Jawab Sosial Perusahaan Dan Mekanisme Tata Kelola Perusahaan Terhadap Nilai Perusahaan. E-Jurnal Akuntansi, 15(1), 667-694.

Rimawan, M., \& Aryani, F. (2019). Pengaruh Alokasi Dana Desa Terhadap Pertumbuhan Ekonomi, Indeks Pembangunan Manusia Serta Kemiskinan di Kabupaten Bima. Jurnal Ilmiah Akuntansi Dan Humanika, 9(3), 287-295.

Safitri, A. M., \& Mukaram, M. (2018). Pengaruh ROA, ROE, dan NPM Terhadap Pertumbuhan Laba Pada Perusahaan Sektor Industri Barang Konsumsi Yang Terdaftar di Bursa Efek Indonesia. Jurnal Riset Bisnis Dan Investasi, 4(1), 25. https://doi.org/10.35697/jrbi.v4i1.990

Seth, H., Chadha, S., \& Sharma, S. (2019). Redesigning the efficiency process analysis for working capital models: Evidences from the determinants. Journal of Global Operations and Strategic Sourcing, 13(1), 38-55. https://doi.org/10.1108/JGOSS-04-2019-0029

Setiyawati, Y., \& Hermawan, S. (2018). Persepsi Pemilik Dan Pengetahuan Akuntansi Pelaku Usaha Mikro Kecil Dan Menengah (Umkm) Atas Penyusunan Laporan Keuangan. Riset Akuntansi Dan Keuangan Indonesia, 3(2), 161-204. https:/ / doi.org/10.23917/ reaksi.v3i2.6629

Solihin, D. (2019). Pengaruh Current Ratio Dan Debt To Equity Ratio Terhadap 
Return On Asset (Roa) Pada Pt Kalbe Farma, Tbk. KREATIF : Jurnal Ilmiah Prodi Manajemen Universitas Pamulang, 7(1), 115. https:// doi.org/10.32493/jk.v7i1.y2019.p115-122

Sopyan, S., \& Perkasa, D. H. (2019). Pengaruh Debt To Equity Ratio, Return on Asset Dan Price Earning Ratio Terhadap Harga Saham Pada Sub Sektor Makanan Dan Minuman Yang Terdaftar Di Bursa Efek Indonesia Tahun 20122016. Jurnal Ilmu Manajemen Terapan, 1(2), 97-107. https://doi.org/10.31933/jimt.v1i2.51

Suhaeni, Magdalena Marpaung, A. (2017). Analisis Perputaran Modal Kerja Terhadap Basic Earning Power (BEP). 5(1).

Sukarmiasih, N. M., Sinarwati, N. K., \& Atmadja, A. T. (2015). Analisis Pengaruh Economic Value Added (Eva) Momentum, Net Profit Margin (Npm), Basic Earning Power (Bep), Return on Assets (Roa), Return on Equity (Roe) Terhadap Return Saham Dan Market Value Added (Mva). E-Journal S1 AK Universitas Pendidikan Ganesha, III(1), 1-11.

Suryani, E., \& Fajaryani, N. luh G. (2018). Struktur Modal , Likuiditas , dan Ukuran Perusahaan terhadap Kinerja Keuangan Perusahaan. Jurnal Riset Akuntansi Kontemporer, 10(2), 74-79.

Suryani Ulan Dewi, N. L. P., \& Sudiartha, I. G. M. (2018). Pengaruh Profitabilitas, Likuiditas, Leverage, Dan Ukuran Perusahaan Terhadap Return Saham Pada Perusahaan Food and Beverage. E-Jurnal Manajemen Universitas Udayana, 8(2), 932. https:// doi.org/10.24843/ejmunud.2019.v08.i02.p13

Susilo, A., Sulastri, S., \& Isnurhadi, I. (2018). Good corporate governance, Risiko Bisnis Dan Kinerja Keuangan Terhadap Nilai Perusahaan. Jurnal Analisis Bisnis Ekonomi, 16(1), 63-72. https:// doi.org/10.31603/bisnisekonomi.v16i1.2132

Trianto, A., Studi, P., Politeknik, A., \& Palembang, D. (2017). Analisis Laporan Keuangan Sebagai Alat Untuk Menilai Kinerja Keuangan Perusahaan Pada Pt. Bukit Asam (Persero) Tbk Tanjung Enim. 8(03).

Trirahaju, J. (2017). Pengaruh Rasio Likuiditas, Solvabilitas, Aktivitas, Profitabilitas Dan Produk Domestik Bruto Terhadap Pertumbuhan Laba Pada Perusahaan Tekstil Dan Garmen Yang Terdaftar Di Bei. Jurnal Riset Keuangan Dan Akuntansi, 1(02). https://doi.org/10.25134/jrka.v1i02.440

Veronika, A., Nangoi, G., \& Tinangon, J. (2019). Pengaruh Profitabilitas, Likuiditas, Leverage, Ukuran Perusahaan dan Opini Auditor Terhadap Ketepatan Waktu Penyampaian Laporan Keuangan Pada Perusahaan Manufaktur yang Terdaftar di Bursa Efek Indonesia Periode Tahun 2012-2016. Jurnal Riset Akuntansi Dan Auditing "Goodwill," 10(2), 136. https://doi.org/10.35800/jjs.v10i2.25611

Wiksuana, I. G. B. (2018). Pengaruh Pendapatan Daerah Terhadap Pertumbuhan Ekonomi Di Wilayah Sarbagita Provinsi Bali. E-Jurnal Manajemen 7(5), 25922620.

Zelmiyanti, R. (2016). Pendekatan Teori Keagenan Pada Kinerja Keuangan Daerah dan Belanja Modal (Studi Pada Provinsi Di Indonesia). 7(1), 11-21. 